\title{
Trusting George Cheyne: Scientific Expertise, Common Sense, and Moral Authority in Early Eighteenth-Century Dietetic Medicine
}

\section{Citation}

Shapin, Steven. 2003. Trusting George Cheyne: Scientific expertise, common sense, and moral authority in early eighteenth-century dietetic medicine. Bulletin of the History of Medicine 77(2): 263-297.

\section{Published Version}

http://dx.doi.org/10.1353/bhm.2003.0091

\section{Permanent link}

http://nrs.harvard.edu/urn-3:HUL.InstRepos:3221079

\section{Terms of Use}

This article was downloaded from Harvard University's DASH repository, and is made available under the terms and conditions applicable to Other Posted Material, as set forth at http:// nrs.harvard.edu/urn-3:HUL.InstRepos:dash.current.terms-of-use\#LAA

\section{Share Your Story}

The Harvard community has made this article openly available.

Please share how this access benefits you. Submit a story.

\section{Accessibility}




\title{
Trusting George Cheyne: Scientific Expertise, Common Sense, and Moral Authority in Early Eighteenth-Century Dietetic Medicine
}

\author{
STEVEN SHAPIN
}

SUMMARY: Whenever physicians give directions to patients there is always a question of their authority to do so: what is it that they know, and who is it that they are, that gives them this authority? The problem is fully general, but it takes especially interesting forms in early modern dietetics, where patients were reckoned to possess much pertinent and reliable knowledge, and where medical dietetics occupied terrain already densely occupied by moral prudence. This article addresses these issues in relation to the writings and practice of George Cheyne (1671-1743), iatromechanist, dietary writer, and fashionable physician. Special attention is given to the relation between Cheyne's scientific expertise and the texture of the advice he gave to two patients, the printer and novelist Samuel Richardson and Selina, countess of Huntingdon.

KEYWORDS: dietetics, physician-patient relations, authority, expertise, common sense

Historically, the physician's role has been precariously poised between expertise and common sense. Insofar as the physician presented himself as an expert, and asked to be accepted as such by those who engaged his services, what he had to say about the causes, course, and possible cure of your condition, as well as the maintenance of health and the attainment of long life, had to be different from mere common sense. You might be skeptical of the good he actually did you (many were not), but insofar as you recognized that he was an expert, you ascribed to him special and superior knowledge about how human bodies work in health and disease.

For comments on earlier versions of this paper I thank Charles E. Rosenberg and Aaron Mauck. 
The physician's expertise might be understood to flow from his vast stock of experience with sick and well people-knowledge of the same sort you had, but in larger store-or that expertise could be constituted by his possession of knowledge not available to you as a layperson, such as knowledge of the hidden structures and processes of your body, its aliment, and the external environment that impinged on your body. ${ }^{1}$

Yet medical expertise was tempered by the knowledge of the people who paid for those expert services. At any time from antiquity through at least the early twentieth century, much of the basic conceptual vocabulary of medical science and art was held in common by medical experts and laity, and it is not easy in many cases to say to whom such vocabulary authentically "belonged." In early modern England, for instance, essentially everybody who interacted with physicians (and many of those who did not) understood what was meant by having a bilious disposition or a scorbutic humor, by being vaporish, by suffering from a tertiary or quaternary fever. They knew what sorts of things clysters and electuaries were; they knew what rhubarb and the Jesuit bark were, and what they were good for; they knew why they were bled, what results were supposed to be produced by bleeding, and why they might be directed to be bled around the equinoxes and solstices. This common culture coordinated interaction between physicians and patients; it made such interaction meaningful; and it was used by the laity to understand what was happening to them and why. Physicians used it to make their expertise manifest to laypeople-and if you wanted to contest the efficacy of medical directions and interventions, the vocabulary of the common culture provided the resources to do that too. Physicians and patients both accepted that laypersons knew a lot about their bodies and the conditions of their health and disease. Even physicians acknowledged that the laity were, to a very large extent, experts on themselves as medical objects. ${ }^{2}$

1. There were, of course, noninstrumental reasons one might engage a physician-e.g., to obtain secular counsel and comfort in times of distress. I use the masculine pronoun here to refer to early modern physicians because of the overwhelming facts of the historical matter; and because, later, references are made to early modern common sayings and proverbs that used the masculine form to designate "people in general."

2. The surgeon was in a different position: in antiquity expertise in, say, cutting for the stone was narrowly distributed and understood to be so. For the notion of a coordinating common medical culture, see, notably, Charles E. Rosenberg, "The Therapeutic Revolution: Medicine, Meaning, and Social Change in Nineteenth-Century America," Perspect. Biol. EF Med., 1977, 20: 485-506; W. F. Bynum, "Health, Disease and Medical Care," in The Ferment of Knowledge: Studies in the Historiography of Eighteenth-Century Science, ed. G. S. Rousseau and Roy Porter (Cambridge: Cambridge University Press, 1980), pp. 211-53, esp. 
This paper is meant as a contribution to understanding some pervasive features of engagements between common sense and expertise. First, I briefly note some historically general circumstances attending dietetic medicine as a culture in which medical expertise and morally textured prudence occupied common terrain. Second, I treat a particular, historically specific site of engagement between expertise and prudence: the case of George Cheyne (1671-1743), a fashionable dietetic doctor who, as a prolific author, also made repeated claims to dernier cri scientific expertise. What did that expertise look like both in his published work and in his quotidian medical practice? How did these claims to scientific expertise figure in securing the doctor's authority and patients' trust in his counsel?

\section{"Every Man His Own Physician": Owning Expertise}

It was commonly said that after thirty years of age-in other versions, after forty or fifty-every man should be his own physician: he then knew enough about his body and its vicissitudes to treat himself, to know which foods and activities agreed with him and which did not, to guess plausibly enough about the course of those common illness which afflicted him. ${ }^{3}$ Montaigne's skepticism about medical expertise was matched by his confidence about dietetic and therapeutic self-knowledge: habit and constitution molded themselves to each other, and everyone who was not a fool came eventually to know best where his own shoe pinched. ${ }^{4}$ Physicians themselves quoted this common wisdom, thereby acknowledging that there was no necessary threat to professional expertise

pp. 228-30; and such exemplars of "the patient's point of view" history as Dorothy Porter and Roy Porter, Patient's Progress: Doctors and Doctoring in Eighteenth-Century England (Stanford: Stanford University Press, 1989).

3. Descartes's version ran this way: "So, as Tiberius Caesar said (or Cato, I think), no one who has reached the age of thirty should need a doctor, since at that age he is quite able to know himself through experience what is good or bad for him, and so be his own doctor" (John Cottingham, ed. and trans., Descartes' Conversations with Burman [Oxford: Clarendon Press, 1976], p. 51). The source is in fact Suetonius's life of Tiberius. In 1645 Descartes told the earl of Newcastle that "I share the opinion of Tiberius, who was inclined to think that everyone over thirty had enough experience of what was harmful or beneficial to be his own doctor. Indeed it seems to me that anybody who has any intelligence, and who is willing to pay a little attention to his health, can better observe what is beneficial to it than the most learned doctors" (quoted in Steven Shapin, "Descartes the Doctor: Rationalism and Its Therapies," Brit. J. Hist. Sci., 2000, 33: 131-54, on p. 139).

4. Michel Eyquem de Montaigne, "Of Experience" [1580], in The Complete Essays of Montaigne, trans. Donald M. Frame (Stanford: Stanford University Press, 1965), pp. 815-57. 
contained in the notion that patients knew quite a lot about themselves as medical objects. Indeed, George Cheyne cited this wisdom on the opening page of his first systematic dietetic text. ${ }^{5}$

Moreover, early modern writers recurrently cited the ancient "Rule of Celsus," which held that people who were in ordinary good health should have no need for a physician or put themselves under the constraint of medical rules. ${ }^{6}$ The proverb "He who lives physically lives miserably" identified the moral and practical dangers of subjecting yourself unnecessarily to the discipline of medical expertise, and lay commentators referred to the commonsensical authority of the Rule of Celsus to argue against the tyranny of those physicians who constantly asserted their authority to order you to live in ways that were unpleasant, inconvenient, and (in skeptics' view) unwarranted by any substantial risks to wellbeing and longevity. ${ }^{7}$ Physicians themselves sometimes invoked the Rule to show that they acknowledged the moral and pragmatic limits of aggressive professional expertise: asserting your expertise did not have to mean that you had taken leave of your common sense. ${ }^{8}$

5. "It is a common Saying, That every Man past Forty is either a Fool or a Physician" (George Cheyne, An Essay of Health and Long Life [London, 1724], p. 1). See also idem, Natural Method of Cureing the Diseases of the Body, and the Disorders of the Mind depending on the Body (London, 1742), p. 47: "These ... general Laws . . . will best serve the End of Health, especially when every one, after a certain Age, becomes his own Physician"; and cf. A Letter to George Cheyne, M.D. F.R.S. Shewing the Danger of laying down General Rules to Those Who are Not Acquainted with the Animal Oeconomy, EFc. . . Occasion'd by his Essay on Health and Long Life (London, 1724), p. 6: "It is a common Saying, as you observe, that a Man past Forty, is either a Fool, or a Physician; and if it means any thing, it only implys, that by so long experience, a Man that is not a Fool, will know what things have best agreed with him; and his Reason will direct him to continue the Use of them, till some alteration in his Constitution makes them hurtful."

6. In its original version, the Rule went: "A man in health, who is both vigorous and his own master, should be under no obligatory rules, and have no need, either for a medical attendant, or for a rubber and anointer. His kind of life should afford him variety" (Aulus Cornelius Celsus, De medicina, trans. W. G. Spencer, 3 vols. [London: Heinemann/Cambridge: Harvard University Press, 1960], 1: 43).

7. For the Rule in a popular medical text by a nonprofessional, see Thomas Elyot, The Castel of Helthe (London, 1541), p. 45r: "as Cornelius Celsus saith, A man that is hole and well at ease, and is at his lybertie, ought not to bynde him selfe to rules, or nede a phisition."

8. E.g., Laurent Joubert, The Second Part of the Popular Errors [1587], trans. Gregory David de Rocher (Tuscaloosa: University of Alabama Press, 1995), p. 263: the healthy man "while he is feeling well, belongs to himself and does not have to follow any rule or diet nor consult a physician"; John Arbuthnot, An Essay Concerning the Nature of Aliments, and the Choice of Them, according to the Different Constitutions of Human Bodies ..., 4th ed. (1731; London: J. and R. Tonson, 1756), pp. 178-79: "a healthy Man, under his own Government, ought not to tie himself to strict Rules, nor to abstain from any Sort of Food in common Use"; James 
So far as prognosis and diagnosis were concerned, laypeople might reasonably come to know enough about common illnesses, the early signs of their appearances, and the course they tended to take in their bodies, to reckon themselves possessed of relevant expertise. And even in therapeutics laypersons might sometimes legitimately juxtapose their expertise to that of physicians, as they might come to acquire sufficient familiarity with common drugs and procedures to know which worked on them and which did not. ${ }^{9}$ Apollo's oracle said "Know thyself," and many early modern laypeople thought they did know themselves at least as well as, if not better than, any expert physician could.

If this was the case in diagnosis, prognosis, and therapeutics, it was an even stronger sentiment in that very important part of medicine called dietetics (regimen or hygiene). That is because management of the "non-naturals" constituted such a significant portion of quotidian life. How you arranged eating and drinking, evacuations, sleeping and waking, exposure to airs and other environmental features, exercise, and how you managed your emotions, constituted a big part of who you were and of your recognized social worth. In dietetics, that is, medicine pitched its tent on ground already densely occupied by moral common sense. ${ }^{10}$ Medical counsel toward temperance-_nothing too much" was the other dictum carved on Apollo's temple at Delphi-made such common sense because it was at the same time a cherished article of moral prudence. Gluttony was, for example, bad for you, but it was also just $b a d$; temperance, after all, is one of the classical virtues. So when dietetic physicians said that you ought to observe the Golden Mean, they spoke with the joint authority of medical expertise, of common sense, and, sometimes, of divine law. Cheyne wrote that "the infinitely wise Author of Nature has so contrived Things, that the most remarkable Rules of preserving Life and Health are moral Duties commanded us, so true it is,

Mackenzie, The History of Health, and the Art of Preserving It, 3d ed. (1758; Edinburgh, 1760), p. 135: "A man who is sound and strong should ty himself down to no particular rule of diet, nor imagine that he stands in need of a physician."

9. Rosenberg, "Therapeutic Revolution" (n. 2); John Harley Warner, The Therapeutic Perspective: Medical Practice, Knowledge, and Identity in America, 1820-1885 (1986; Princeton: Princeton University Press, 1997).

10. For dietetics and the care of the self, see Michel Foucault, The History of Sexuality, trans. Robert Hurley, 3 vols. (New York: Vintage Books, 1988-90), 2: 97-139; 3: 140-41. Note that "dietetics" (hygiene or regimen) classically included the management of all the non-naturals, and thus that advice on food and drink was only one part of dietetics. Here I use the term in the classical sense, occasionally slipping into a more modern restricted usage when the context makes that clear. 
that Godliness has the Promises of this Life, as well as that to come." 11 This was a powerful combination, and its advice was difficult to deny. ${ }^{12}$

From antiquity through the early modern period, dietetic expertise counseled moderation with very great cultural stability and uniformity. Perhaps that is why dietetics has attracted so little historical attention: its advices seem banal and it is not a culture that changes very much over a great sweep of history. There appear to be no real ideas at play-certainly nothing as headily intellectual as the changes in medical theorizing ushered in with the Scientific Revolution. Of course, the ancient natural philosophy of the elements and the doctrine of natural place underpinned the counsel of moderation, and the same ideas shaped the vocabulary of humors, complexions, and temperaments that allowed physicians to understand the complicated relations between individuals, aliments, environment, and medically directed measures. But both the stability of those ideas and their joint ownership by experts and laypeople have seemed unattractive to scholars who conceive of the history of medicine as the history of its novel ideas. ${ }^{13}$

This joint ownership of dietetic culture could give physicians great authority, just as long as what they advised counted as common sense. However, the same cultural sharing also presented them with problems in asserting their expert authority, just because their counsel might appear as little else than common sense, or even, where it departed from

11. Cheyne, Health and Long Life (n. 5), p. 5.

12. This is systematically argued in Steven Shapin, "How to Eat Like a Gentleman: Dietetics and Ethics in Early Modern England," in Right Living: An Anglo-American Tradition of Self-Help Medicine and Hygiene, ed. Charles E. Rosenberg (Baltimore: Johns Hopkins University Press, 2003), pp. 21-58. See also Keith Thomas, "Health and Morality in Early Modern England," in Morality and Health, ed. Allan M. Brandt and Paul Rozin (New York: Routledge, 1997), pp. 15-34; Margaret Pelling, "Food, Status and Knowledge: Attitudes to Diet in Early Modern England," in idem, The Common Lot: Sickness, Medical Occupations and the Urban Poor in Early Modern England (London: Longman, 1998), pp. 38-62.

13. For ancient natural philosophy and dietetics, see esp. Owsei Temkin, Galenism: Rise and Decline of a Medical Philosophy (Ithaca: Cornell University Press, 1973); Raymond Klibansky, Erwin Panofsky, and Fritz Saxl, Saturn and Melancholy: Studies in the History of Natural Philosophy, Religion, and Art (London: Thomas Nelson, 1964), chap. 1. See also Ludwig Edelstein, "The Dietetics of Antiquity" [1931], in idem, Ancient Medicine: Selected Papers of Ludwig Edelstein, ed. Owsei Temkin and C. Lilian Temkin (Baltimore: Johns Hopkins Press, 1967), pp. 303-16; Owsei Temkin, Hippocrates in a World of Pagans and Christians (Baltimore: Johns Hopkins University Press, 1991); Henry E. Sigerist, "Galen's Hygiene," in idem, Landmarks in the History of Hygiene (London: Oxford University Press, 1956), pp. 1-19. For a valuable recent survey of early modern dietetics, see Heikki Mikkeli, Hygiene in the Early Modern Medical Tradition, Annals of the Finnish Academy of Sciences and Letters, Humaniora, no. 305 (Helsinki: Academia Scientiarum Fennica, 1999). 
temperate prudence, as less than common sense. From the physician's point of view - though not, of course, from the patient's-dietetics held out limited possibilities for cultural and social distinction. As dietetics was such an important part of the physician's role, this was the predicament wrestled with in much of the late Renaissance and early modern literature on popular "medical errors." Proverbial common sense advertised itself as containing all you really needed to know of physic: "Piss clear and make a fig at physicians"; "He who pisses, sleeps, and wags well has no need of Doctor Bell"; "Kitchen physic is the best physic"; "A good cook is half a physician"; "Use three Physicians still; first Doctor Quiet, next Doctor Merry-man, and Doctor Dyet."14 This was the sort of stuff opposed by Laurent Joubert and other medical critics of "popular errors": the "ungrateful common people" are always likely to give themselves and their commonsense beliefs and practices the credit that rightfully belongs to learned expertise, just as they "forget rather easily the benefits they receive [from physicians' care] and retain in memory the most insignificant mistakes"; they attribute to "all nature's doing" or to "good soups" what was really done by physicians with their rational expertise, their uniquely effective dietetic advice, and their well-judged therapeutic interventions. ${ }^{15}$

\section{Medical Expertise and Micromechanism}

The late seventeenth and early eighteenth centuries witnessed radical changes in the cultural conditions of medical expertise and its relations with common sense. The micromechanism of Descartes, Gassendi, Boyle, Borelli, and, above all, Newton testified to an invisible realm qualitatively different from that posited by the Aristotelians or by commonsense actors. When the corpuscles of micromechanism took the place of the four elements, there were new implications and opportunities for physiological

14. The first two proverbs are cited as examples of popular error in Laurent Joubert, Popular Errors [1579], trans. Gregory David de Rocher (Tuscaloosa: University of Alabama Press, 1989), p. 247; the next two are proverbs common in early modern England; the last is found in Sir John Harington, The English Mans Doctor. Or the Schoole of Salerne (London, 1607), a volume that embodies both formal medical wisdom and robust lay common sense. See also Morris Palmer Tilley, A Dictionary of the Proverbs in England in the Sixteenth and Seventeenth Centuries (Ann Arbor: University of Michigan Press, 1950). Some other texts in the "popular medical errors" tradition include Gaspard Bachot, Erreurs populaires touchant la médecine et régime de santé (Lyons, 1626); Jacques Primerose, De vulgi erroribus in medicina (Amsterdam, 1639); Luc d'Iharce, Erreurs populaires sur la médecine (Paris, 1783); and Balthasar-Anthelme Richerand, Des erreurs populaires relatives à la médecine (Paris, 1810).

15. Joubert, Second Part of Popular Errors (n. 8), pp. 117-18. 
and medical expertise. ${ }^{16}$ Iatromechanism and iatromathematics were platforms from which the advanced physician could speak for an invisible realm publicized as more securely founded than that which it was bidding to supplant, and, moreover, whose natural-philosophical champions were rapidly turning into powerful cultural allies. Francis Bacon had complained that there would be no progress in medical practice until medicine acquired reformed natural-philosophical foundations. ${ }^{17}$ With Newton's work, such foundations were considered to be available, ready to be exploited by physicians mathematically and philosophically able to do so. Now that such physicians definitively knew the microstructures and micromechanisms of aliment and the body, they could intervene and advise with radically improved effectiveness. Micromechanism ambitiously promised the maintenance of health, the cure of disease, and the prolongation of human life. ${ }^{18}$

The "rational physician" traditionally distinguished himself from the vulgar "empirick" because he alone systematically grasped the fundamental underlying causes of health and disease. Among learned and fashionable physicians in early- to mid-eighteenth-century Britain, the display of iatromechanical expertise was a powerful vehicle for cultural

16. See Theodore M. Brown, "The College of Physicians and the Acceptance of IatroMechanism in England, 1665-1695," Bull. Hist. Med., 1970, 44: 12-30; idem, "Physiology and the Mechanical Philosophy in Mid-Seventeenth-Century England," ibid., 1977, 51: 2554; Harold J. Cook, "Physicians and the New Philosophy: Henry Stubbe and the VirtuosiPhysicians," in The Medical Revolution of the Seventeenth Century, ed. Roger French and Andrew Wear (Cambridge: Cambridge University Press, 1989), pp. 246-71; Arnold Thackray, Atoms and Powers: An Essay on Newtonian Matter-Theory and the Development of Chemistry (Cambridge: Harvard University Press, 1970), pp. 49-51; Robert E. Schofield, Mechanism and Materialism: British Natural Philosophy in an Age of Reason (Princeton: Princeton University Press, 1970), chap. 3; Anita Guerrini, "James Keill, George Cheyne, and Newtonian Physiology, 1690-1740," J. Hist. Biol., 1985, 18: 247-66; idem, "The Tory Newtonians: Gregory, Pitcairne and Their Circle," J. Brit. Stud., 1986, 25: 288-311; idem, "Archibald Pitcairne and Newtonian Medicine," Med. Hist., 1987, 31: 70-83; idem, "Isaac Newton, George Cheyne and the 'Principia Medicinae," in French and Wear, Medical Revolution (n. 16), pp. 222-45; idem, "The Varieties of Mechanical Medicine: Borelli, Malpighi, Bellini, Pitcairne," in Marcello Malpighi: Anatomist and Physician, ed. D. Bertoloni Meli, Nuncius, 1997, 27: 111-28; Andrew Cunningham, "Sydenham versus Newton: The Edinburgh Fever Dispute of the 1690s between Andrew Brown and Archibald Pitcairne," in Theories of Fever from Antiquity to the Enlightenment, ed. W. F. Bynum and Vivian Nutton, Supplement no. 1 to Med. Hist. (London: Wellcome Institute, 1981), pp. 71-98; Gerrit A. Lindeboom, Descartes and Medicine (Amsterdam: Rodopi, 1979).

17. E.g., Francis Bacon, "The Advancement of Learning [Books I-II]," in idem, The Philosophical Works of Francis Bacon, ed. James Spedding, Robert Leslie Ellis, and Douglas Denon Heath, 5 vols. (London: Longman, 1857-58), 3: 253-491.

18. Shapin, "Descartes the Doctor" (n. 3), esp. pp. 143-46. 
product-differentiation. The Scottish iatromathematician Archibald Pitcairne advertised the professional advantages that would flow from adopting Newtonian principles: the "infamous Mark of Uncertainty" would be erased from medicine, and "the Honour of our Profession" would no longer be at "the Mercy of the Vulgar." ${ }^{19}$ And Richard Mead announced that soon "Mathematical Learning will be the Distinguishing Mark of a Physician from a Quack.”20

That is how George Cheyne started his medical and literary career, well narrated in Anita Guerrini's now-indispensable recent biography. In the 1720 s John Woodward satirically counseled professionally ambitious physicians newly arrived in London "to make all the Noise and Bustle you can, to make the whole Town ring of you if possible: So that every one in it may know, that there is in Being, and here in Town too, such a Physician." ${ }^{21}$ When Cheyne removed from Edinburgh to London in 1702, the instrument of his "Noise and Bustle" was A New Theory of Continual Fevers, an aggressively iatromathematical tract inspired by his mentor Pitcairne. ${ }^{22}$ The display of Newtonian expertise was one way to make yourself known; association with London's literary and philosophical fast crowd was another. Within months of his arrival in London, Cheyne secured election to the fastest philosophical club of all, the Royal Society. A great talker, and, at the time, a very great trencherman and drinker, he cruised the coffeehouses and the taverns, where he "found the Bottle-Companions, the younger Gentry, and Free-Livers, to be the most easy of Access, and most quickly susceptible of Friendship and Acquaintance."23

After a rocky start, Cheyne eventually established himself not only as a fashionable physician-shuttling between London and his main base in Bath-but also as one of England's most influential medical authors. His clientele included Alexander Pope, John Gay, Beau Nash, Samuel

19. Archibald Pitcairne, The Whole Works of Dr Archibald Pitcairn, trans. George Sewell and J. T. Desaguliers, 2d ed. (London, 1715), p. 19; quoted in Anita Guerrini, Obesity and Depression in the Enlightenment: The Life and Times of George Cheyne (Norman: University of Oklahoma Press, 2000), p. 40 (see also p. 66).

20. Richard Mead, A Mechanical Account of Poisons in Several Essays (London, 1702), unpaginated preface; quoted in Guerrini, Obesity and Depression (n. 19), p. 67.

21. John Woodward, The Art of Getting into Practice in Physick, Here at Present in London (London, 1722), p. 10; quoted in Guerrini, Obesity and Depression (n. 19), p. 56.

22. George Cheyne, A New Theory of Continual Fevers (London, 1701; 2d ed. with additions, London, 1702).

23. George Cheyne, The English Malady: Or, A Treatise of Nervous Diseases of All Kinds, as Spleen, Vapours, Lowness of Spirits, Hypochondriacal, and Hysterical Distempers, $\mathcal{F}^{2}$. (London, 1733), p. 325. See also Guerrini, Obesity and Depression (n. 19), pp. 59-60. 
Richardson, the Methodist countess of Huntingdon, Robert Walpole's adolescent daughter, Catherine (who died under Cheyne's care of something resembling anorexia nervosa), and the earl of Chesterfield (who passed Cheyne's advice ineffectively on to his "dear boy"). Cheyne's published medical advice was favorably quoted in Tom Jones; Samuel Johnson commended his books; and John Wesley in his Primitive Physick copied out whole sections of Cheyne's work.

Historians of medicine sometimes say that around 1720 Cheyne "repudiated his youthful mathematical brashness and excessive Newtonian enthusiasm." ${ }^{24}$ In this "second phase" of his career, he refashioned himself into a dietetic doctor, centering his attention on chronic conditions, and prudently counseling "moderation in diet and drink." ${ }^{25}$ Certainly, dietetics did become the focus of Cheyne's publishing career, and this did represent a considerable change from earlier writings that elaborated micromechanical accounts of the human body relatively disengaged from streams of practical hygienic counsel. ${ }^{26}$ General dietetic advice was the meat of such works as An Essay of Health and Long Life (1724), An Essay on Regimen (1740), and Natural Method of Cureing the Diseases of the Body (1742), while his popular Essay on the Gout (1720) and the celebrated The English Malady (1733) commended a largely dietary regime in dealing with both conditions.

By the 1730 s and 1740 s the whole polite British world was talking about Cheyne and his diet. While he did indeed counsel moderation for people in normal good health-even articulating a version of the Rule of Celsus $^{27}$ - the diet for which he was famous was a severe "lowering" regime, suited to the valetudinary, the sedentary, the studious, and the otherwise fine-nerved, who, he warned, were risking their lives by persisting with a normal course of food and drink: "I advise ... all Gentlemen of a sedentary Life, and of learned Professions, to use as much Abstinence as possibly they can," in extremis descending to an exclusive regime of

24. Theodore M. Brown, "Cheyne, George," Dict. Sci. Biog., 3: 244-45, on p. 244.

25. Eric T. Carlson, introduction to George Cheyne, The English Malady, facsimile ed. (Delmar, N.Y.: Scholars' Facsimiles and Reprints, 1976), pp. v-xii, quotation on p. vii.

26. Indeed, a few colleagues even feared that Cheyne's turn to dietetics, by identifying general rules of health, would undermine that medical authority which flowed uniquely from practitioners' arduously acquired knowledge of particularities: Guerrini, Obesity and Depression (n. 19), pp. 129-30.

27. George Cheyne, An Essay on Regimen (London, 1740), pp. xiv-xv: "I think [it] is true, just and philosophical [that] while Youth and tolerable Health continues, none ought to alter the common temperat Diet of the middling Rank of those among whom he lives, for a particular or artificial one, without a particular Call, and the best Advice"; see also p. xxxvi. 
asses' milk and seeds. ${ }^{28}$ Many people swore by Cheyne's lowering diet, announcing that it had saved their lives; others swore at it, considering it bizarre, unbalanced, rigidly doctrinaire, unnecessary, impossible to maintain, and probably totally ineffective. ${ }^{29}$ (By 1740 Cheyne was sufficiently aware of his critical identification with the weird milk-and-seed diet that he took pains publicly to deny that he recommended it to any but those in desperate need of its cooling effects.) ${ }^{30}$ In this primarily dietetic work, Cheyne may well have moved away from his earlier iatromechanical and iatromathematical "enthusiasms," but he did not "repudiate" his claims to micromechanical expertise. Indeed, all of the texts he published from 1720 on explained and justified his medical interventions by reference to this expertise.

So Cheyne appeared in the person of an expert author, subject to all of the interests, irritations, conventions, and constraints of the authorial life in early eighteenth-century England. At the same time, he appeared in the person of a fashionable physician, purveying face-to-face and epistolary diagnoses, prognoses, dietetic counsel, and therapeutic prescriptions to patients with whom he was often intimately familiar. A large number of letters survive from Cheyne to two of his patients in the 1730s and 1740s: the printer and novelist Samuel Richardson (1689-1761), and Selina, countess of Huntingdon (1707-91). ${ }^{31}$ It is this sort of evidence,

28. Cheyne, Health and Long Life (n. 5), p. 36. "Seeds" in Cheyne's usage seem to have designated grains and grain-derived foods, from sago and rice puddings to porridge and bread.

29. For critical responses, see, e.g., Edward Strother, An Essay on Sickness and Health; . . . in which Dr. Cheyne's Mistaken Opinions in His Late Essay, are occasionally taken Notice of, 2d ed. (London, 1725), esp. pp. 28, 209-22; Letter to George Cheyne (n. 5), esp. pp. 11-13; Guerrini, Obesity and Depression (n. 19), pp. 128-31.

30. Cheyne, Essay on Regimen (n. 27), pp. xiii-xiv, xliii.

31. The Letters of Dr. George Cheyne to the Countess of Huntingdon, ed. Charles F. Mullett (San Marino, Calif.: Huntington Library, 1940) (hereafter LH); The Letters of Doctor George Cheyne to Samuel Richardson (1733-1743), ed. Charles F. Mullett, University of Missouri Studies, vol. 18, no. 1 (Columbia: University of Missouri Press, 1943) (hereafter LR). These letters are at least as important for writing the history of the English book-trade as for the history of medical practice. The former set contains about forty letters written from 1730 to 1739; the latter, about eighty. The reciprocal letters to Cheyne do not survive, though much of their content can be inferred from Cheyne's end of the correspondence. The letters also permit an assessment of aspects of Nick Jewson's important thesis about the relationship between the social standing of patients and the physician's position vis-à-vis disease individuality: see N. D. Jewson, "Medical Knowledge and the Patronage System in EighteenthCentury England," Sociology, 1974, 8: 369-85; idem, "The Disappearance of the Sick-Man from Medical Cosmology, 1770-1870," ibid., 1976, 10: 225-44. See also Roy Porter, "Lay Medical Knowledge in the Eighteenth Century: The Evidence of the Gentleman's Magazine," Med. Hist., 1985, 29: 138-68; Malcolm Nicolson, "The Metastatic Theory of Pathogenesis 
considered side-by-side with public displays of scientific expertise, that allows one to reconstruct some of the complex and often edgy interrelations between medical theory and practice, expertise and prudential common sense, public professions and private counsels, the general and abstract and the particular and concrete, in early to mid-eighteenthcentury England. What did iatromechanical expertise look like when confronted with an individual sick patient? How did such expertise figure in quotidian medical practice? And how was this expertise implicated, together with other features of Cheyne's knowledge, life, and character, in securing the credibility of his claims and the authority of his practical advice?

\section{Medical Expertise and the Invisible World}

The overall framework of Cheyne's iatromechanism is not radically different from that of other early eighteenth-century English Newtonian physicians. The human body, he wrote, is "nothing but a Compages or Contexture of Pipes, an hydraulic Machin." ${ }^{2}$ The "elasticity" of the body's solids was a pretty durable paternal inheritance-not easy (though not impossible) to alter over time. But the juices came from your mother, and these were readily modifiable by your way of life, and, especially, by your food and drink; that is the general philosophical explanation of why the primary task of the dietetic physician was to tend the juices: if these could be mended by expert dietetic advice, "they will in time . . . rectify and confirm the Solids into their proper Situation and Tone." ${ }^{33}$ In health, the fluids enjoyed free passage through the canals; diseases resulted inter alia from obstruction to that flow. The expert rational physician could mathematically model blood flow and could demonstrate the precise causal links between the particulate configurations of aliments and their effects on fluid flow. That expertise was what allowed him to give good advice: "Art can do nothing but remove Impediments, resolve Obstructions, cut off and tear away Excrescences and Superfluities, and reduce Nature to its primitive Order; and this only can be done by a proper and specific Regimen in Quantity and Quality." ${ }^{34}$

and the Professional Interests of the Eighteenth-Century Physician," ibid., 1988, 32: 277300 . In these cases, while the correspondence is strongly marked by a recognition of relative social standing, both the printer and the countess are granted the personal individuality of their diseases.

32. Cheyne, Essay on Regimen (n. 27), p. iii. See also Guerrini, Obesity and Depression (n. 19), p. 57.

33. Cheyne, Essay on Regimen (n. 27), p. iv.

34. Ibid. See also $L R, 2$ February 1742, pp. 82-83. 
The "Grand Secret" of health and long life was, in principle, quite simple: it was "to keep the Blood and Juices in a due State of Thinness and Fluidity, whereby they may be able to make those Rounds and Circulations through the animal Fibres, wherein Life and Health consist, with the fewest Rubs and least Resistance that may be." ${ }^{35}$ But if, through age and improper diet, the fluids become "viscid, thick and glewy," the circulation slows and ultimately stops, producing first disease, then death. ${ }^{36}$ The English Malady commenced with a causal explanation of "Chronical Distempers" in general, the paramount cause being a "Glewiness, Sizyness, Viscidity, or Grossness in the Fluids." ${ }^{77}$ The "best Blood" was the "thinnest and most fluid Blood," as it "most easily circulates thro' the capillary Vessels, which is the most solid Foundation of good Health and Long Life." ${ }^{8}$

One was to understand, therefore, that Cheyne's advice to eat this and not eat that, to take the drugs and embrace the other therapeutic measures he prescribed, and to adopt specific regimens of exercise, proceeded from his deep and systematic knowledge of the invisible world, and that the quality of this expertise was in large part vouched for by its derivation as a deduction from Newtonian natural philosophy and mathematics. Cheyne's special contribution was to put flesh on this deductive skeleton, to identify the micromechanical structures of particular aliments and body parts. His books also assured readers that he could bring this fleshed-out framework to bear on the management of particular sick bodies. Indeed, he wrote that he had repeatedly and successfully done so, most spectacularly described in the extraordinary thirty-page "The Case of the Author" appended to The English Malady: in curing himself by largely dietetic means, Cheyne announced, he had cured by far his hardest case. ${ }^{39}$

Cheyne's books identified a number of ways to keep the blood and other bodily juices thin, sweet, and flowing. Exercise was important; so

35. Cheyne, Health and Long Life (n. 5), p. 220.

36. Ibid., p. 222.

37. Cheyne, English Malady (n. 23), p. 6. See also idem, Health and Long Life (n. 5), pp. 172-75. Cheyne tended to avoid the practical management of "acute," "epidemical," or "contagious" diseases—e.g., fevers, plague, and smallpox—noting that his dietary regime might not preserve those who embraced it from such distempers: Cheyne, Essay on Regimen (n. 27), p. xv. But his dietetic books repeated his earlier causal accounts of fevers, and his suggested remedies bore a close resemblance to his dietary regime for chronic conditions: Cheyne, Natural Method (n. 5), pp. 96-111.

38. Cheyne, Health and Long Life (n. 5), p. 224.

39. George Cheyne, "The Case of the Author," in English Malady (n. 23), pp. 222-51; and see Anita Guerrini, "Case History as Spiritual Autobiography: George Cheyne's 'Case of the Author," Eighteenth-Century Life, May 1995, 19: 18-27. 
were air, bloodletting, and the judicious use of drugs, but "it is Diet alone, proper and specific Diet, in Quantity, Quality and Order, that continued in till the Juices are sufficiently thinn'd, to make the Functions regular and easy, which is the sole universal Remedy." 40 "A thin, fluid, spare and lean Diet" made for thin and free-flowing juices. ${ }^{41}$ Here Cheyne clearly had the force of analogy on his side: the ultimate particles of thin and fluid aliments were themselves thin and fluid, while gross and sharply flavored foods and drinks were made up of large and angular particles, likely to scrape the vessels and to deposit an obstructing crust on them. The authority of micromechanical expertise thus helped itself to the very analogy between visible and invisible that was formally denied by the distinction between primary and secondary qualities. ${ }^{42}$ As a dietetic physician, Cheyne acknowledged the obligation to identify the vices and virtues of specific aliments, transforming micromechanical expertise from abstract pronouncements to particular counsels.

Consider Cheyne on water-drinking: "Pure Water," he wrote, is "the only Beverage designed and fitted by Nature for long Life, Health and Serenity." 43 To drink water as your sole dietary liquid "is the only Preservative, I am certain, known or knowable to Art." ${ }_{44}$ If you started with a course of exclusive water-drinking when young, and persisted with it, you "would live probably till towards an hundred Years of Age." 45 Water is the "true and universal Panacea, and the Philosopher's Stone." ${ }^{46}$ Despite the confident promise of longevity, this was radical advice, seriously unpopular in free-toping Georgian England; Cheyne appreciated that it could be justified only on the strongest philosophical grounds, and these grounds were duly supplied. ${ }^{47}$ The ultimate particles of water were so fine and smooth that this was the "sole Fluid that will pass through the smallest animal Tubes without Resistance." 48 The microstructure of water was what made it such a good solvent of vascular obstructions and such an effective vehicle for keeping the juices flowing. Cheyne understood that water in

40. Cheyne, Essay on Regimen (n. 27), p. x.

41. Cheyne, Health and Long Life (n. 5), p. 225.

42. On this crucial, but little noticed, feature of seventeenth- and eighteenth-century micromechanism, see Alan Gabbey, "The Mechanical Philosophy and Its Problems: Mechanical Explanations, Impenetrability, and Perpetual Motion," in Change and Progress in Modern Science, ed. Joseph C. Pitt (Dordrecht: Reidel, 1985), pp. 9-84.

43. Cheyne, Essay on Regimen (n. 27), p. xxiii.

44. Ibid., p. xxv.

45. Ibid., p. xxiv.

46. Ibid., p. lviii.

47. Cheyne, Natural Method (n. 5), pp. 57-58.

48. Cheyne, Essay on Regimen (n. 27), p. lxii. 
its naturally occurring states also contained dissolved in it "a little fine vegetable Earth, Salt and Sulphur"-the "smallest and finest" of such particles-and, accordingly, possessed powerful nutritive as well as therapeutic properties. ${ }^{49}$

All aliment contained in various combinations the principles of sulphur ("from whence Spirit and Activity"), salt ("hard angular" and highly attractive particles), water ("from whence alone Fluidity"), and earth ("the base and Substratum of these others"). ${ }^{50}$ Cheyne averred that "it is past all Doubt in Philosophy, and in philosophical Chem[istr]y," that animal foods were richer in the first two principles, while vegetable foods were richer in air, water, and earth ${ }^{51}$ From "undeniable Experiments," it was philosophically known that the first two principles are "the most active, energic, and deleterious, and tend more, by their Activity, to the Division, Dissolution and Destruction of the Subject, than those others when they enter in any great Proportion." ${ }^{52}$ Of these invisible states of affairs, "there are so many and convincing Demonstrations, that none can have any Doubt of it, that has the least Acquaintance with natural Philosophy. ${ }^{53}$ Expertise was that sure of the matter:

Infinite Experiment, and the best natural Philosophy, confirm to a Demonstration, that those Substances, which have least of Salt and Sulphur, of Spirit, Oil, and hard pungent Particles, and most of soft Earth, Water and Air, are the fittest to circulate, and be secreted through animal Tubes, create least Resistance to the motive Powers, tear, rend, and wear out the Tubes themselves least, and form less obstinate and powerful Obstructions, in the smaller Vessels. ${ }^{54}$

Water was not only good in itself, but it might, over time, wash away the incrustations caused by the micromechanical structure of animal foods

49. Ibid., p. 117. As a spa physician, Cheyne, like many others of his sort, advertised special expertise in knowing the constituents and effects of mineral waters from different sources, especially those of Bath, Bristol, Cheltenham, Clifton, Islington, Pyrmont, Spa (or "Spaw"), and Tunbridge: see George Cheyne, Observations Concerning the Nature and Due Method of Treating the Gout, . . . Together With an Account of the Nature and Qualities of the Bath Waters (London, 1720). See also Roy Porter, ed., The Medical History of Waters and Spas, Supplement 10 of Med. Hist., 1990; Katharine Park, "Natural Particulars: Medical Epistemology, Practice, and the Literature of Healing Springs," in Natural Particulars: Nature and the Disciplines in Renaissance Europe, ed. Anthony Grafton and Nancy Siraisi (Cambridge: MIT Press, 1999), pp. 347-67 (for fourteenth- and fifteenth-century thinking).

50. Cheyne, Essay on Regimen (n. 27), p. 56.

51. Ibid.

52. Ibid.

53. Ibid., p. 57.

54. Ibid., p. 60. 
and strong liquors, restoring the vessels to their naturally elastic and healthy tone. ${ }^{55}$

Expertise in advising regimens of food and drink was therefore said to proceed from privileged knowledge of the micromechanical realm, and such philosophically informed regimens were of central importance to Cheyne's professional practice. Yet he never confined himself to dietetic advice, and the same expertise in testifying about the realm of the invisibly small was also brought to bear on his bleeding and drugging practices. Consider Cheyne's views- to be sure, not unique to him-on the properties and medical virtues of mercury: The therapeutic virtues of mercury also proceeded from its micromechanical structure. The particles of mercury are the smallest of any known fluid; they are the most perfectly spherical, the heaviest, and the most extremely attractive and repulsive. It follows that mercury is, of all substances, the most easily raised by heat; it possesses the greatest momentum; and it is the most able "to pass through all animal Substances, which are lax and porous. ${ }^{{ }^{56} 6}$ Physiologically, this meant that mercury was uniquely suited to break up viscid and gluey accretions clogging up the vessels. And from these physiological capacities, the specific medical uses of mercury deductively followed: mercury was the most powerful medicine against scurvy, palsies, gout, and, indeed, all the "chronical Distempers caus'd by Excesses. ${ }^{.57}$ Even so, knowing all this about mercury was not sufficient to its safe and effective curative use: mercurial medicines had to be prepared with exquisite care. Its degree of fineness was crucial to mercury's action, either as a powerful antidote or as a dangerous poison, so the physician had to be responsible for selecting, supervising, and validating the work of the preparing apothecary or chemist. ${ }^{58}$

While the authorial display of micromechanical expertise identified Cheyne as a rational physician, the inclusion of case histories (notably in The English Malady) and discussions of the causes and cures of common chronic illnesses advertised the concrete pertinence of his knowledge and his effectiveness in matters of pressing concern to existing and prospective patients. Natural Method of Cureing Diseases, for example, showed his philosophical expertise and proprietary regimen powerfully at work in a long list of chronic distempers, including rheumatism, dropsy, gout, colic, sciatica, the stone, and menstrual complaints. In the

55. Ibid., p. xxvi.

56. Ibid., p. 266.

57. Ibid.

58. Ibid., pp. 266-67; see also ibid., pp.109-11. See also Cheyne, Natural Method (n. 5), pp. 119-26, 150; LH, 28 August 1734, p. 43 (for practical directions). 
case of scurvy, Cheyne told readers what the disease was in micromechanical terms, and how his method worked to cure or alleviate it. The manifestations of scurvy were various and diffuse, including "an habitual white, or foul crusted Tongue"; a reddish sediment in the urine expressed during the night; and a long series of "Hysteric and nervous Symptoms," such as alternating chills and burning sensations in the extremities, dermatological eruptions, vomiting, interrupted sleep, thirst on waking, depression, convulsions, and flatulence. ${ }^{59}$ The micromechanical cause of all this was, again, "viscid Juices," the saturation of the blood and other body fluids with "saline, sulphurous, or firy Particles," obstructing the circulation, the perspiration, and, ultimately, blocking the viscera and the nervous system. ${ }^{60}$ Accordingly, the appropriate method for dealing with scurvy, or a tendency toward it (a "scorbutic habit" or "humour"), centered on the dietary thinning of the fluids - for example, by drinking "sweet Cow-whey" and eating a "light white-meat trimming Diet," with little or no fermented liquors: "Living on Milk and Vegetables . . . will keep this Distemper long under." 61 Mercury and phlebotomy could be judiciously used to aid the thinning process, while rhubarb, aloes, or other emetics might be employed to free up the bowels. By this method, Cheyne wrote, he had rarely failed "of a perfect Cure, or a notable Relief," except in cases very far advanced. ${ }^{62}$ You had to consult Cheyne early enough, or even his formidable expertise might not save you.

\section{Intimate Relations: Cheyne and His Patients}

So far, this story has remained in the public realm, describing the philosophical and practical expertise that Cheyne published in the books written from the 1720 s until close to his death in 1743 . What configurations of expertise, prudence, and authority are evident when one shifts attention to the relatively private sphere of Cheyne's medical practice? Here the letters to Samuel Richardson and the countess of Huntingdon are major sources of evidence. ${ }^{63}$ Both patients were well known to Cheyne:

59. Cheyne, Natural Method (n. 5), p. 191.

60. Ibid., pp. 191-92.

61. Ibid., pp. 193, 195.

62. Ibid., p. 195. And see Cheyne, Health and Long Life (n. 5), pp. 178-80, where scurvy is identified as "a kind of Catholick Distemper here in Britain," owing to climate and dietary customs.

63. Cheyne's medical practice is treated in Guerrini, Obesity and Depression (n. 19), chap. 5. Besides the Richardson and Huntingdon cases, Guerrini also uses letters Cheyne wrote to Hans Sloane about his medical management of Catherine Walpole in the early 1720s. 
he treated various members of the extended aristocratic family over many years, and he had business relations with Richardson as printer of several of his medical books. The social pleasantries exchanged in the letters establish intimacies that possibly passed the norm in early eighteenth-century doctor-patient relationships, while Cheyne accorded to the correspondents the mode of civility appropriate to their social standing-fawning deference to the countess, and a kind of affectionate condescension to the tradesman-printer, whom Cheyne praised for an integrity rare in people of his sort and who benefited from the good doctor's prescriptions for effective novel-writing. ${ }^{64}$

Both patients also stood in an intimate relationship with Cheyne because both were made to understand that their conditions were similar to those suffered by the doctor himself. Symptomatology was evidently agreed between physician and patients: with few exceptions, Cheyne accepted not only their reports of signs and feelings, but also the vocabulary they used to report those signs and feelings. ${ }^{65}$ At the start of the correspondence, Richardson suffered from the classic complex of signs that Cheyne designated the "English Malady" (hypochondriasis, "the Hyp," or "the nervous Hyp"): that combination of vertigo, paroxysms, "Giddiness and Lowness," and "terror and confusion" that Cheyne's English Malady so vividly described in his own case. ${ }^{66}$ Paramount in Lady Huntingdon's sufferings was severe and persistent constipation, but she also reported extreme itchiness (possibly hemorrhoids, as the correspondence gets coy on the matter), an erysipelous skin condition, flatulence, gripes, colic, hot flashes, occasional unspecified complaints about her eyes, menstrual irregularities (she was continually pregnant during the

64. $L R, 10$ February 1738, p. 36: "I have a sincere Regard for you and am convinced that you are a Man of Probity and Worth beyond what I have met among Tradesmen." On Cheyne instructing Richardson how to write a better novel than Pamela, see LR, 24 August 1741, pp. 67-70. Cheyne took no fees from Richardson for his medical counsel, but did extract at least part of the equivalent in printing and publishing services: $L R, 9$ August 1735 , p. 32 .

65. Nevertheless, if he was so inclined, Cheyne was quick to reject patients' identification of the condition from which they were suffering; see, for example, his dissent from Lady Huntingdon's report that she was then afflicted with the "stone, gravel, or [a] hurt bowel": $L H$, 19 November 1733, p. 29. See also LH, 18 February 1734, p. 37.

66. "We call the Hyp every Distemper attended with Lowness of Spirits. Whether it be Flatulence from Indigestion, Wind Cholic, Head-Pains, or an universal relaxed State of the Nerves, with Numbness, Weakness, Startings, Tremblings, etc., so that the Hyp is only a Short Expression for any Kind of nervous Disorder with whatever Symptoms (which are various nay infinite) or from whatever Cause" ( $L R$, 5 September 1742, p. 108). See also Cheyne, English Malady (n. 23), pp. 222-51. 
period of her correspondence with Cheyne), and a series of "distracting, sinking nervous complaints." ${ }^{67}$ While some of these complaints were attributed to her being constantly "a-breeding"-one of the few conditions from which Cheyne did not claim his own "crazy Carcase" suffered-he traced the ultimate roots of many others to an underlying disposition that was said to be remarkably similar to his own case. ${ }^{68}$

Cheyne's medical counsel to both Lady Huntingdon and Richardson was very various. It definitely included aggressive drugging, bleeding, and the active management of all the non-naturals. Over the course of ten years, a small selection of the drugs that Cheyne regularly directed Lady Huntingdon to take included Anderson's (or the Scotch) pill (a mild aperient), Jesuit's bark (quinine, a febrifuge but apparently widely taken for a diffuse range of complaints), rhubarb (a common purgative), senna (a cathartic and emetic), ipecac (emetic, diaphoretic, and purgative), spirit of lavender, laudanum and other opiates (for pain and sleeping problems), Glauber's salt (sodium sulphate, a purgative and laxative), cream of tartar (potassium bitartrate, an emetic), and "cinnabar of antimony" (cinnabar usually designated a mercuric sulphide, but Cheyne warned of the dangers of "active mercurial medicines" in her case)—often elaborately compounded to the doctor's precise instructions, and washed down with lashings of mineral water, Bristol or Pyrmont by preference. ${ }^{69}$ Richardson was dosed with enormous quantities of mercury in various forms (as purgative and cathartic), the Jesuit bark, squill (a botanic diuretic), ipecac, hiera picra and aloes (botanic purgatives), ethiops mineral (probably a sulphide of mercury), asafoetida (an antispasmodic), spirit of niter (for the relief of flatulence), "tincture of soot" and powdered steel (purposes unknown), and various extracts of spruce and fir-often compounded together, and, as with Lady Huntingdon, taken with Spa or Pyrmont water. (Cheyne disapproved of Richardson's preference for Tunbridge. $)^{70}$

Both patients were directed frequently to be bled, for diagnostic as well as therapeutic purposes. And both were prescribed the precise forms of light exercise: Lady Huntingdon was told to ride abroad (when her pregnancies permitted), while Richardson (who loathed any form of

67. LH, 12 August 1732, p. 9 .

68. Cheyne, Health and Long Life (n. 5), p. xvi.

69. LH, 19 July 1732 , p. 4; 12 August 1732, p. 8.

70. For specimen complicated prescriptions, see $L R, 9$ August 1735, p. 33; LH, 19 November 1733, p. 29. For disapproval of Tunbridge water, see LR, 24 October 1741, p. 72. See also Guerrini, Obesity and Depression (n. 19), p. 132. Like Lady Huntingdon, Richardson disliked Bath, though Cheyne tried hard to get both of them to take the waters there. 
exercise) was evangelized on the virtues of the then-fashionable hobby(or chamber-)horse: "It is certainly admirable and has all the good and beneficial Effects of a hard Trotting Horse except the fresh Air." "7l Cheyne pursued a vigorous regime of vomits, induced both chemically and manually—but, perhaps surprisingly, these were commended not so much for the lightening of the load on the stomach as for the exercise they afforded the body. His proprietary method of "Thumb Vomits" was minutely detailed to Richardson (the countess was spared this method): "the Virtue lies in the Exercise, the Throws and Pumpings of the Cavities; 40 or 50 Kecks is more Exercise of the whole Body than half a Dozen Miles Coaching." 72 Daily thumb vomits "work the whole Man and shake every Fibre and Gland which cannot be otherwise reached." " Lady Huntingdon was diffusely counseled to maintain a cheerful frame of mind and an optimistic view of her case, while Richardson was offered explicit expert advice on how to manage the emotional terrors of the authorial life (writer's block and bad reviews): "Now as to yourself I never wrote a Book in my Life but I had a Fit of Illness after." ${ }^{\prime 4}$

Although Cheyne evidently struggled with Richardson to get him to take the recommended exercise, in the main the letters offer no evidence that the prescribed bleedings and polypharmacy met with much resistance from the patients. For all the elaborateness of Cheyne's prescriptions, and for all the obvious inconvenience and unpleasantness of having to spend so much of your life on the water closet, his practice here seemed well within local norms. ${ }^{75}$ The matter was quite otherwise with his program for food and drink. Here Cheyne was obliged to confront a serious conflict between his dietary counsel and the demands of common sense, civility, and appetite. And here the patients did indeed resist ("I find . . . you go on timorously, grudgingly, and repiningly," he told Richardson), ${ }^{76}$ and Cheyne had to bring to bear all the resources at his command to secure his authority and their assent to his advice.

71. $L H, 19$ November 1733, p. 26; 29 December 1733, p. 31; quotation from $L R$, 20 April 1740 , pp. 59-60. Walking was all right too, even to the point of "lassitude": $L R, 12$ February 1741 , p. 66.

72. $L R, 2$ April 1742, p. 90.

73. $L R, 30$ June 1742 , p. 101.

74. LH, 19 November 1733, p. 29. See also LH, 29 December 1733, pp. 31-32; LR, 24 August 1741, p. 69; and see the editor's introduction to $L R$, pp. 18-19, for Richardson's enthusiastic use of the chamber-horse (he never learned to ride a real horse).

75. See James C. Whorton, Inner Hygiene: Constipation and the Pursuit of Health in Modern Society (Oxford: Oxford University Press, 2000), for the nineteenth- and twentieth-century history of costiveness.

76. $L R, 10$ January 1742 , p. 81. 
In both of the cases at hand, Cheyne wound up ordering his patients to adopt a radically lowering milk-and-seed diet. At the start of their correspondence, he was not seriously concerned about Richardson's condition: "All your Complaints are vapourish and nervous, of no Manner of Danger."77 Accordingly, he saw no reason to urge on Richardson anything more than "that general Temperance I have so often recommended to you and which I know you pursue." 78 Abstinence from wine and fermented liquors was good, but moderation in all food and drink would do nicely: "One Dish of plain Fish or Flesh at Dinner, at Supper a Toast with another Half Pint of Wine and Spaw Water with a Bit of Cheese, and the ordinary Breakfast"; ${ }^{79}$ there might even be "Times and Seasons when a little Indulgence in Chicken . . . may not only be convenient but necessary." ${ }^{80}$ Why not "Half a Chicken in Quantity of any fresh tender Meat (any Thing else to fill Chinks you please)"? ${ }^{81}$ But already by the summer of 1741 the doctor was beginning to be seriously concerned that Richardson had taken a "Plunge" and was now in immediate danger of a fatal apoplexy; Cheyne would not answer for his patient's life if a radically restricted regimen was not followed precisely: "You had as good shoot yourself as alter your Diet." ${ }^{2}$ The doctor's advice then became more extreme, and he ordered Richardson onto a totally vegetarian and wineless diet. By the spring of the next year, Richardson was encouraged to embrace the pure milk-and-seed regimen, asses' milk for preference: "at Dinner Rice Pudding, and at Night Watergruel or Milk Porridge." ${ }^{83}$ Hunger was the best medicine, and Richardson had to learn to live with gnawing hunger and a miserable diet or, Cheyne assured him, he would not live at all.

Lady Huntingdon was also started out on a "cool and tender regimen," but nothing too severe: lashings of sweet cow's whey and waterdrinking provided the base; ripe fruit was all right ("as much as you please") and salads too, if they agreed; at dinner, she was permitted to rise as high as "Chicken, partridge, a little white fish, lobster, cray fish, lambstons [lamb's testicles?], veal feet, [and] jellies." ${ }^{84}$ Pregnancy further

77. $L R, 16$ July 1739 , p. 54.

78. $L R, 12$ September 1739 , p. 57.

79. $L R, 3$ February 1739 , p. 47.

80. $L R, 10$ January 1742 , p. 80.

81. $L R, 22$ June 1738 , p. 38.

82. $L R, 19$ April 1742, p. 91.

83. LR, 26 April 1742, p. 92. See also ibid., 19 April 1742, p. 91; and ibid., 2 May 1742, p. 95. Evidently, Richardson accepted some of this advice over a long period of time, for he became widely known for his vegetarianism.

84. LH, [ca. 1732], p. 16. 
warranted an easy regime: Lady Huntingdon was reminded that she had two to feed and was told, accordingly, to "Let your appetite be your rule." ${ }^{85}$ But after a year and a half of this treatment (including active drugging) her condition did not respond, and Cheyne urged her first to carry on with the temperate diet and then, with a show of sympathetic reluctance, to lower it further-alternating a light main meal of white meats with one of milk-and-seeds: "Milk is the only certain and infallible remedy" for her condition; 86 "Live as much as you can on milk and milk meats" ${ }^{87}$ no fermented liquors; "a bit of chicken now and then for a relishing of spirits." ${ }^{88}$ The total milk-and-seed diet might yet be avoided if only she would follow Cheyne's directions religiously. A year later, her complaints persisting, Cheyne ordered her to be lowered still further: "I think milk and rice, sago, barley, or bread the best emulsion and diet for you." ${ }^{\prime 9}$ Asses' milk would, of course, be best, but the countess evidently stuck at that point. ${ }^{90}$ From then on, Cheyne's letters fine-tuned Lady Huntingdon's diet, constantly urging her to keep on course and promising an ultimate return to ordinary victuals when the low regime had at last worked its healing effects. Normal life could then resume. ${ }^{91}$

\section{Trusting George Cheyne}

Cheyne had to work hard at getting his patients to adopt his diet and to stick to it. Both his side of the exchanges and contemporary satire indicate the extent of lay resistance: as influential as he was, many eighteenth-century English readers found his dietary prescriptions ludicrous, impossible, unlikely to do anyone any good-while much of his medical correspondence with his patients is constituted by a continual battle for practical and moral authority. What resources were available to him to secure this authority and patients' assent? Why would you agree to do that to yourself when so much about Cheyne's regime violated dietetic tradition, contemporary common sense, and moral prudence?

The first thing that might be done by a physician counseling such extreme measures would be to represent this kind of diet as itself a form of temperate common sense, to respecify an apparent extreme as a

85. LH, 28 August 1732, p. 10; see also ibid., [ca. 1732], p. 15.

86. $L H, 19$ November 1733, p. 28.

87. Ibid., p. 29.

88. LH, 7 January 1734, p. 33.

89. $L H, 19$ October 1734, p. 46.

90. $L H, 6$ September 1735, p. 51.

91. LH, 20 August 1737, p. 59. 
prudentially sanctioned Golden Mean. So when Cheyne was advising Richardson only to reduce his consumption of meat and wine, he said "you may keep the golden Mediocrity by thus trimming"; ${ }^{2}$ when he urged him on to "a Fleshless and Wineless Diet," he commended it as "a just Medium between a Common Animal and Wine Diet, and a Milk Diet"; ${ }^{93}$ and when, finally, he directed Richardson to adopt the asses' milk regime, he shifted attention to the total amount of aliment to be consumed, describing that as "a just Mediocrity." 94 The prudential Golden Mean could also be reckoned through a social calculus. Even with the lowering measures pressed on him by Cheyne, Richardson was assured that his diet "will still be fuller and higher, more nourishing and salutary than Nine Parts of Ten in England can have"; 95 "All below Farmers scarce taste Animal Food Six Times a Year . . . and yet one Tenant is generally supposed to out-live Three or Four Landlords at an Average. These have few or no natural Distempers except epidemical Ones." 96 Throughout the early modern period, the prudential Golden Mean remained such a powerful cultural resource that there were always contests for the rights to its blessings. ${ }^{97}$

Extreme dietetic advice might also be smoothed in its course by embedding itself in the rhetorical forms of common sense. Counsel that everybody recognized as prudential wisdom was hard to gainsay. The Hippocratic aphorism stipulating that "desperate diseases require desperate remedies" had long passed into common usage, applied in a wide range of nonmedical as well as medical contexts. When Cheyne was confronted by patients' reluctance to follow what even he acknowledged to be extreme measures, he asserted his expertise by telling them that their condition had become so serious that mere temperance was no longer enough: "Extreme cases must have extreme cures," he wrote to Lady Huntingdon, ${ }^{98}$ and Richardson similarly was motivated to compliance by being told that "a desperate Disease must only have a desperate Remedy." ${ }^{99}$ Proverbial common sense was pervasively used as an emollient wrapping for bizarre and unpleasant expert counsel: "you must take

92. $L R$, 20 June 1739 , p. 52.

93. $L R, 12$ December 1741, p. 75.

94. $L R, 26$ April 1742, p. 92.

95. $L R, 7$ December 1741 , p. 74.

96. $L R, 23$ December 1741, p. 76.

97. See my treatment of Francis Bacon's respecification of dietary moderation in Shapin, "How to Eat Like a Gentleman" (n. 12).

98. LH, 3 August 1734, p. 41.

99. $L R, 7$ December 1741, p. 74 . 
Care of the Brute else he will be at last too hard for the Man"; 100 "The Disease must in a Manner be starved"; 101 "He who is in the Fire should get out as fast as he can"; 102 "Custom is no Reason." "103

Other means for asserting his dietary authority responded to more skeptical sentiments among his patients. When Cheyne evidently felt that Lady Huntingdon and Richardson were wandering off-message, he pointed to his track record in many previous cases-to healthy and happy patients who were vibrantly living testimony to the efficacy of the dietary method, and even to a primitive form of statistical evidence. So he reminded Lady Huntingdon of the pertinent case of the cleric who first inspired him to his present dietetic method. This man had totally cured himself of epilepsy by living for twenty-two years "on a total rigid milk diet" —not even any bread, fruit, or vegetables; then, when he was persuaded by his family and friends to resume a "higher, tho even, temperate, diet," his former condition reasserted itself, and he "perished miserably under it." ${ }^{104}$ On a more positive note, the countess was put in mind of two patients suffering from the same scorbutical humor that afflicted her, who, keeping to Cheyne's diet, were now "big . . . healthy and gay," and he enclosed in this letter a copy of a letter he had received from "a vegetable [eater] of 72 years"- "a considerable person in the House of Commons"-who had thus recovered from "mortal agonies." 105 Family members also treated by Cheyne were now looking "fresh, clear, and plump" by virtue of their milk-and-vegetable diet, ${ }^{106}$ and there were several Cheyne-advised low-living neighbors, now "gay as a bird," whom

100. $L R$, [ca. April 1740], p. 61.

101. $L R, 23$ December 1741, p. 77.

102. $L R, 10$ January 1742 , p. 79 .

103. $L R, 12$ September 1739, p. 57. Proverbs and aphorisms were used to similar effect in Cheyne's published work: "Diseases are always to be cured by their Contraries" (Hippocratic); "He that would be soon well, must be long sick" (Essay on Regimen [n. 27], p. lx); "He that is old when he is young ... will be young when he grows old in Years" (ibid., p. lxii). But, as scholars of orality have pointed out, the natural home of proverbs is the oral rather than the literate domain: see Steven Shapin, "Proverbial Economies: How Some Social and Linguistic Features of Common Sense Can Throw Light on More Prestigious Bodies of Knowledge, Science for Example," Soc. Stud. Sci., 2001, 33: 731-69, on pp. 737-38.

104. $L H, 3$ November 1735 , pp. 52-53. This medical casuistry-the vivid and dramatic retelling of successfully treated cases-was also a notable feature of Cheyne's published work, particularly English Malady (n. 23), pp. 177-256. My interest here is in the different moral texture and force of such case histories when they figured in the context of intimate relations.

105. $L H, 15$ April 1734, p. 39.

106. $L H, 18$ February 1734, p. 38. 
Lady Huntingdon could visit, and whose good health gave witness to the power of the method. ${ }^{107}$

To Richardson, Cheyne enclosed a personal letter from a satisfied patient, and also a statistical summary of his vast experience in such matters: "In at least 30 Years Practice" in cases such as Richardson's,

and all the other incurable Cases by Drugs or Doctors in which I have treated some Hundreds and of which many are yet alive over all the Dominions of His Majesty and some Abroad I do not remember to have lost above Three, and they were too far gone and died in the Beginning of their Course. One or two more I have lost by being over persuaded by eminent Physicians to alter their Method, but never one that I had the most remote Reason to ascribe their Failure to their Diet, nor do I think the Thing possible. Some indeed do not recover to that high, athletic Health some strong young Beef-eaters enjoy but that is because they have had originally broken, tender, debilitated Constitutions from their Fathers or began [the method] too late in Life, . . . but never one who continued in it 2 or 3 Years that did not live out the natural Duration of their Lives and went on infinitely easier than they did before they entered upon it. I have Letters every Post from some one or other such from all Parts of the Kingdom. ${ }^{108}$

However, in these intimate epistolary settings, the invocation of statistics appears as a less-central feature of credibility management than the assertion of a moral compulsion. Cheyne's exchanges with his patients took place on a moral and emotional field: following the doctor's expert but difficult advice became a mark of personal virtue. Again and again, his patients were urged to be courageous. When they showed signs of reluctance to go on with his radically abstemious dietary regime, they were told to summon up the courage to persevere, until they were "brought to perfect health and gayety at last."109 To Richardson: "Courage! you will come to laugh at your own Fears"; 110 "take Courage"; 11 you must have the courage to stand against both your animal appetites and the ridicule of your friends. ${ }^{112}$ Patients needed patience: the cure takes time, and courage is the virtue required to let the medicine work its inevitable curative effects. As Cheyne rather unfortunately told Lady

107. $L H, 19$ November 1733, pp. 26-27.

108. LR, 30 December 1741, pp. 78-79. The testimonial was enclosed with the letter of 2 November 1742, pp. 115-17. See also ibid., 9 March 1742, p. 86.

109. $L H, 29$ December 1733, p. 30.

110. LR, 9 March 1742, p. 88.

111. LR, 27 March 1738, p. 48.

112. LR, 7 December 1741, p. 74; 30 December 1741, p. 78. 
Huntingdon, "the lightest and the least, tho slow, is as certain as death." 113 This virtue was not gendered: Lady Huntingdon was applauded in just the same way as Richardson for the "courage to go on steadily"; 114 for her "resolution, and courage to enter upon such a course of self denial"; 115 for her stout refusal "to be sneered, ridiculed, nor frightened" out of her regime. ${ }^{116}$

The doctor encouraged his patients, and, in turn, they were applauded for their displays of dietary courage: the relationship was a mutual tuning of the virtues. They owed dietary persistence to themselves (of course), but also to their friends and family. Richardson was promised material benefits as the undoubted result of his compliance: he would get to "a moderate, Active, gay Temper and Habit and write Books without End, as I have done, and grow rich as a Jew and settle all your Family to your Heart's Content." 117 Both Richardson and Lady Huntingdon were repeatedly told that their restoration to health, and therefore their persistence in Cheyne's regime, were moral obligations they owed to those who loved and depended upon them. Here the virtue of courage was joined to that of fidelity.

His patients' return to health was also enmeshed in a network of reciprocal moral obligations with their physician. Cheyne worked hardpossibly harder than any British physician of his time-to produce and sustain such obligations. His patients were repeatedly given to understand that he had suffered what they were suffering. Practically speaking, this meant two things: that his experience was not merely theoretical, and that the efficacy of his method could be vouched for by his own nowhealthy, but once seriously ill, body. Time and again, Cheyne reassured Lady Huntingdon and Richardson that his condition was the same as, or similar to, their own. ${ }^{118}$ If Richardson complained of a pain in his ears, Cheyne "had it often" and knew what cured it; ${ }^{119}$ when the printer was bothered by "Startings, Twitching, and Cramps" making him apprehensive, Cheyne sent him a complicated prescription, and assured him that

113. $L H, 12$ May 1736, p. 57.

114. LH, 12 August 1732, p. 8.

115. $L H, 28$ August 1732, p. 10.

116. $L H, 28$ August 1734, p. 44.

117. LR, 2 February 1742, p. 83. See also ibid., 14 July 1742, pp. 103-4: "Continue your Diet for God's Sake, your Life's Sake, and your Family's Sake."

118. Given the diffuseness of eighteenth-century vocabularies for designating chronic illnesses, that was not a difficult matter, though physicians still had to make moral and practical judgments that such shared experiences should be a basis for interaction.

119. LR, 4 June 1739, p. 50. 
"I took it myself some Months" with good effects; $;{ }^{120}$ when Richardson had a worrying "Plunge" early on in the radically lowering diet, the doctor consoled him with the information that he himself had experienced such a relapse, even a year and a half or two years into the regime: but that was "16 or 17 Years ago, and now at 70 you know I am tolerably well."121 To the lay injunction "Physician, cure thyself," Cheyne had a robust response: he had done so.

Both Richardson and Cheyne were fat-at about 450 pounds Cheyne was spectacularly so ("overgrown beyond any one I believe in Europe") ${ }^{122}$ and, while obesity was not then in itself a medical complaint, it brought about physical inconveniences that might become medically consequential. Physician-patient intimacy reached its height when Cheyne, encouraging Richardson to keep on his low diet, shared with the printer a disgusting obesity-induced disorder that "is a Secret to all the World except to my own Family": "my Guts fell out through the Cawl where the Spermatic Vessels perforate it made a Kind of Wind Rupture"; diet and thumb vomits cured that too. ${ }^{123}$ Again, hernias and child-bearing apart, Cheyne's ability to feel your pain was not notably gendered. The English Malady afflicted men and women alike, and Cheyne both understood and sympathized with Lady Huntingdon's underlying scorbutic humor and "erisipelatous" outbreaks:

I have had more of that distemper than anyone I ever heard, I believe above 40 times, and it was the principal reason why I entered upon a milk and vegetable diet, . . . and just now, by indulging too freely in high, rich vegetables, growing too fat, using too little exercise, ... I have suffered the most universal erisipelas ever was known. ${ }^{124}$

Cheyne bound himself emotionally to his patients because he had suffered their pain, but also because he himself had at times fallen away from "the dietetical Ghospel" just as they were in imminent danger of doing. ${ }^{125}$ Only a sinner knew the true value of salvation. ${ }^{126}$

120. $L R$, 6 June 1740 , p. 62.

121. LR, 14 July 1742, pp. 102-3. See also Guerrini, Obesity and Depression (n. 19), pp. $103,169$.

122. $L R, 23$ December 1741 , p. 76.

123. Ibid., pp. 76-77.

124. $L H, 18$ February 1734, p. 38.

125. $L H, 25$ February 1737, p. 58.

126. The religious framing of much of Cheyne's dietary counsel is pervasive, and his close involvement with Lady Huntingdon's Methodist circle is thoroughly documented in Guerrini, Obesity and Depression (n. 19), chaps. 5-6. 
Cheyne also gave his patients to understand that he cared for them very much. His relationship with them incorporated expertise, but it was never merely instrumental. The letters between the doctor and his patients exchanged civilities, inquiries after the health and doings of friends and family members, and notifications of gifts about to be sent and of gifts gratefully received. From Lady Huntingdon's family there came occasional presents of venison (only partly foul) ${ }^{127}$ from Richardson, repeated gifts of oysters (only sometimes spoiled). ${ }^{128}$ Cheyne recommended servants to Lady Huntingdon and sought personal favors from her for his brother. ${ }^{129}$ Repeatedly, he assured both patients of his deep and abiding concern for their well-being. He cared for them, and loved them, as he did himself, and he would not commend to them any measures but those most certain of success. On this "I will venture my life and reputation," he told Lady Huntingdon;130 "as to your life, I could venture mine a thousand times for the security of it."131 Urging Richardson to adopt his dietetic regime, Cheyne would "venture my Life" on a successful outcome, ${ }^{132}$ and later said that he would "go to Death for it."133 Cheyne told Richardson that he loved him as he would a family member, and he would no more give bad advice to Richardson than he would to a brother, son, or father. ${ }^{134}$ In such a relationship, the only interest Cheyne could conceivably have was in his friend's well-being-and so he told Richardson: "If I have either Honour, Honesty, Friendship, or Virtue I would not suffer a Man who trusts me, is my Friend on whom I have no Views, to run Risques." 135 To Lady Huntingdon he wrote that if she failed to improve on his regime "I am a cheat and a deceiver"; if she had "any trust to give me," would she really suggest that someone who loved her would tell her a damaging lie? ${ }^{136}$

Cheyne asked, even demanded, to be trusted. He wanted, of course, to be trusted as an expert, but more than that, he wanted to be trusted as someone who would bring his expertise to bear on his patients' cases-

127. $L H, 6$ September 1735 , p. 49.

128. LR, 21 December 1734, p. 31; 31 January 1736, p. 33; 29 November [1739], p. 44; 7 November 1740 , p. 62.

129. $L H$, 20 September 1734, p. 45; 4 September 1733, p. 24.

130. LH, 4 September 1733, p. 23.

131. LH, 9 August 1735, p. 48.

132. $L R, 12$ September 1739 , p. 57 .

133. $L R, 2$ May 1742, p. 95.

134. LR, 2 May 1742, p. 94; 17 May 1742, p. 98; 10 January 1742, p. 81.

135. LR, 9 March 1742, p. 86. See also 17 May 1742, p. 98: "What Interest can I have in being thus bigoted?"

136. LH, 19 November 1733, p. 29. 
conscientiously, prudently, heroically (if necessary), and with as much skill and art as he would in his own case. It is one thing to acknowledge expertise; it is another to accept that this expertise will be diligently brought to bear on your behalf. Cheyne asked to be trusted even in the extremities of his dietetic method, and the reciprocal ties of moral obligation gave adequate grounds for doing so. It was not easy to withhold such trust from a friend, and especially to do so in intimate relations.

Where is natural-philosophical expertise in all this? In fact, displays of micromechanical knowledge figure not at all in these exchanges. Cheyne never instructed Lady Huntingdon or Richardson about the ultimate particles of their juices or aliment, or about the corpuscular causes of their conditions. Occasionally, he reasserted his superior knowledge of the underlying causes of their various symptoms. Lady Huntingdon was several times reminded that all her complaints proceeded from "that sharp scorbutic humour you brought into the world with you," which made her ailments so difficult to alleviate quickly using dietetic methods. ${ }^{137}$ Similarly, Richardson was told that his problems resided in the solids and not in the juices: "I take it your Solids are loose, flabby, and soft though fresh and sound like untwisted Silk Threads"; through poor diet and habits early in his life, the "original lax Membranes and Vessels" were filled too full, "and they being somewhat broken are not sufficiently strong and elastic to force out the perspireable Wind and Steams which being retained perpetuate on the Membranes." 138 In only one instance in these exchanges did Cheyne even gesture at knowledge of a more fundamental ontological level. Sometime in 1742, Richardson sought the opinion of another physician. ${ }^{139}$ This physician recommended a course of chemical medicines that Cheyne had always opposed. Accordingly, Cheyne reminded Richardson of his superior natural-philosophical knowledge:

I have studied Chemistry and read most of all the Rational and Philosophical Chemists, but never could make any Thing of them that I could rely on, and even despise Boerha[a]ve for his wild Brags of some of his chemical Medicines which I have ever found false on frequent Trial. . . . I never saw a chemical Medicine of any Kind that I could not over-match with a natural and simple one. ${ }^{140}$

137. LH, 6 September 1735, p. 49. See also ibid., 14 April 1736, p. 55.

138. $L R, 6$ June 1740 , p. 61.

139. Such consultations were not exceptional in either case. Cheyne knew that both of his patients were receiving advice from other practitioners, and even from friends and family. Whether or not this bothered him depended upon the precise circumstances of the consultations.

140. $L R,[1742$ ?], p. 96 . 
On the other hand, when Cheyne was confronted with outbreaks of special obstinacy, he was willing to remind both patients that he himself was the author of books in which the natural-philosophical foundations of his regimen were systematically set out. The countess was intermittently informed of Cheyne's books in which such cases as hers were competently addressed. In 1737, he told her that he was about to complete another book, then to be titled "the Universal Remedy," which Cheyne believed "will hit my lord and your ladyship's taste." ${ }^{41}$ He requested permission to dedicate the book-which eventually appeared in 1740 as the Essay on Regimen - to Lord Huntingdon, which he did do, though at the time the two had never met. At the same time, Cheyne was aware that his noble patrons might not be especially interested in such things: the book was "chiefly designed for learned and philosophical men, [so] I fear there might be reckoned some impropriety" in begging leave for this dedication. ${ }^{142}$

Richardson too was occasionally referred to the systematic principles set out in Cheyne's published work, but evidently with a somewhat greater expectation that these books might actually be consulted. ${ }^{143}$ By 1742, Cheyne was expressing a degree of special irritation that Richardson showed little familiarity with the doctor's treatises, since it was Richardson, after all, who saw them through the press: "It is a surprize to me that you, [who] have printed 3 or 4 of my Books wherein all the Turns, Symptoms, Nature and Cause of nervous Disorders are narrated and accounted for, should seem to know as little of the Affair as if you had never seen them." ${ }^{44}$ Even the very literary man who had printed Cheyne's expert works appeared to have little need of their formal and systematic expert counsel.

\section{Expertise in Action}

What sort of thing is this expertise that laypeople might recognize, desire, and, possibly, evaluate? One kind of expertise can be called

141. LH, 20 August 1737, p. 60. See also ibid., 19 November 1733, p. 29; ibid., 3 November 1735, p. 54.

142. $L H, 19$ May 1739 , p. 61.

143. E.g., $L R, 13$ May 1739, p. 49; 12 September 1739, p. 57: "pray read and consider my Essay on Regimen"; 23 December 1741, p. 77: "I wish you would look into the Essay on Regimen"; 30 December 1741, p. 79: "I wish you would only read the Cases in my Book of the English Malady for your Amusement."

144. $L R, 2$ February 1742 , p. 82. 
prudential. ${ }^{145}$ Such expertise is possessed by, for example, a thoracic surgeon who has done very many coronary by-pass operations; by a restaurateur who has opened, and closed, lots of restaurants; by a car mechanic who has seen hundreds of faulty Ford transmissions; by a marriage counselor who has accumulated experience of the tensions in a May-December relationship; and, of course, by your grannie in regard to all sorts of things that depend on a large experience of life and its vicissitudes. Prudential expertise must not be thought of as just the property of commonsense actors: very highly trained professionals may possess such expertise, and it may, indeed, be definitive of their role and authority. However, the nature of prudential expertise is that it need not pretend to flow from a knowledge of underlying processes that is reckoned qualitatively different from, or superior in kind to, lay knowledge. You could be such an expert if you had "been around the houses" as much as the acknowledged prudential expert. It is accumulated experience, and the judgment that is informed by that experience, that matters here. A great surgeon might be a poor physiologist, but that need not matter.

There is another kind of expertise that can be called ontological. This expertise bases its claim to authority on the possession of special knowledge about the underlying or hidden structures of the world or of the domain in question. Such knowledge is argued to be different in kind from that held by lay actors or by prudential experts in the same domain-or it might be said that ontological experts alone penetrate behind appearances to hidden realities. As is the case with all such formal distinctions, there is no reason to think that the types of expertise map very neatly onto actual social roles: the prudential expert may happen to know something about the hidden world, and the ontological expert may well possess considerable prudential knowledge. It is a rare theoretician who is totally devoid of practical common sense. Nonetheless, the modes of expertise are analytically distinct. It is not impossible to imagine the one without_or almost without — the other: the marriage counselor who has never been married and who takes her theories off the shelf; the business executive who makes no claims to knowledge in the areas of rational decision theory or the sociology of organizations.

Such a distinction between types of expertise seems to make some obvious sense in the history of medicine. Indeed, it maps easily onto

145. "Prudential expertise" is preferred here to the apparently more straightforward "experience" because of the latter's referential richness, and because "prudence" carries with it the wanted sense of orientation to judgment and action: wisdom or experience applied to practical action. 
empirically consequential battles over social roles and their attendant values. If in the eighteenth century you pretended to be a "rational" physician, your identity and worth flowed from some version of ontological expertise whose power was contrasted with the "empirick's" inadequate, superficial, and unreliable merely prudential knowledge. ${ }^{146}$ Yet, although the "rational" physicians tended to write most of the books, the empirics were not without a comeback: prudential knowledge was soundly based on things that mattered, particular sick bodies-while claims to ontological expertise were unreliable and unverifiable. Ontological medical expertise was no new thing in the late seventeenth and early eighteenth centuries, but the corpuscular and mechanical philosophies of the Scientific Revolution provided it with new forms and bases for cultural authority. Cartesianism and Newtonianism gave ontological expertise a novel language to assert itself, a language that identified both its own foundational status and its divorce from the categories and vocabularies of everyday experience. That is what the Galilean distinction between primary and secondary qualities was about: where the ultimate structures of the physical world were concerned, appearances were deceiving. You could not see the ultimate particles of roast beef or blood vessels, for example; you had to take their characteristics on trust from an expert who had securely deduced their existence.

We now have a pretty good understanding of how such displays of ontological expertise figured in the professional contests of English Restoration and Augustan medicine. Iatromechanism and iatromathematics were used, inter alia, as professional displays: when you wrote a book about the micromechanical structure of the human body and its aliments, you could establish your authentic standing as a rational physician and even your superior rationality vis-à-vis other physicians. That was good for you in the professional community, and there was a reasonable expectation that standing in the professional community might translate into a lucrative practice. Fashionable patients might be presumed, after all, to want intellectually, as well as socially, fashionable doctors. ${ }^{147}$

146. To be sure, there might be other attributions involved in the identity of the "empirick" in the early modern period, such as a penchant for medical "specifics" and attendant "quackery"; see here Roy Porter, Health for Sale: Quackery in England 1650-1850 (Manchester: Manchester University Press, 1989).

147. For literature on the importance of fashionability for the eighteenth-century British medical career, see, e.g., Christopher J. Lawrence, "Ornate Physicians and Learned Artisans: Edinburgh Medical Men, 1726-1776," in William Hunter and the Eighteenth-Century Medical World, ed. W. F. Bynum and Roy Porter (Cambridge: Cambridge University Press, 1985), pp. 153-76; Roy Porter, "William Hunter: A Surgeon and a Gentleman," in ibid., pp. 7-34. 
Just as the micromechanism of the natural philosophers was identified as a radical break with Scholasticism, so iatromechanism could provide an intellectual license for radically new medical practices. George Cheyne, buttressed by the cultural authority of the new ontological expertise, took on a drastic reconfiguration of dietetics, perhaps the most stable and traditionally entrenched of all domains of medical practice. It was in large measure because Cheyne advertised his new ontological expertise that he took the risk publicly to defy dietetic tradition and common sense. The counsel of temperance might give way to a milk-and-seed diet because, in some professional circles, ontological expertise was accounted such a powerful cultural commodity.

So far as the laity are concerned, it is probably banal to say that they want their physicians to be experts. But how medical expertise is parsed, between its prudential and ontological forms, and how it is given content, are historically and sociologically contingent matters. There is little evidence that Cheyne's patients cared much, if at all, about his public displays of ontological expertise. Such displays were largely for the benefit of other medical men and philosophers, and if his patients cared about such things at all, it was indirectly-through hearing from friends and family that Cheyne's ontological views were highly esteemed by pertinent physicians and philosophers. ${ }^{148}$ There is more reason to think that some modern middle-class patients do expect their physicians to possess such cutting-edge expertise, or even that some patients reckon they can and should assess such ontological expertise-as occurs, for example, in sophisticated patient-support groups. Nevertheless, even educated patients concerned that their physicians should possess ontological expertise may continue to feel a degree of discomfort with doctors just out of medical school where such expertise has its natural home and is most concentrated. More to the point, all patients care about medical expertise - of whatever sort—not as a theoretical matter, but in deeply personal terms. They want their doctors to possess and deliver relevant expertise. That is to say, they want medical expertise to be brought to bear on their cases_humanely, conscientiously, and effectively.

148. Roy Porter rightly emphasized the extent of eighteenth-century lay medical literacy, but he offered no evidence that such interest extended to micromechanical theorizing. The "theoretical matrix" for lay medical thinking, Porter wrote, "was the ingrained Hippocratic leanings of the Enlightenment gentleman" (Lay Medical Knowledge" [n. 31], p. 151). Guerrini similarly says (Obesity and Depression [n. 19], p. 132) that in Cheyne's time "physicians and patients shared the same explanatory model of disease," but on the evidence presented in this article, such sharing did not commonly include micromechanical explanatory structures. 
The patient's practical task is to assess the credibility of relevant expertise. In principle, that is a very hard thing to do since, by definition, the laity themselves possess neither form of expertise. (If they did, they would be experts themselves.) This means that they have to look for the adequate marks of expertise. If it is prudential expertise, this large pertinent experience has to be vouched for by some visible or audible warrants (for example, those of age, manner, and commonly expressed opinion). If ontological expertise happens to be an issue, then some other visible or audible warrants might be looked for (perhaps the visible marks of learning, the occupation of a role or an institutional habitation widely known for such expertise, and, again, general opinion). So in this connection another distinction is indicated-this time between formal and informal channels for knowing about expertise. In the case of George Cheyne, the formal channel is represented by his books, and the informal channel by his intimate relations, both epistolary and face-to-face, with particular patients.

If we accept that patients are interested in relevant expertise, what are the capacities of the different channels for informing them on such matters? The formal channel cannot do that very well, because the book is not written for you and it is not exactly about you: it might be written for people of your sort in general, or, as Cheyne told Lady Huntingdon, it might be written for another type of audience altogether, a readership of "learned and philosophical men." You really want to know two things together: whether this physician is an expert (in any sense), and whether his or her expertise will be conscientiously and sensitively brought to bear on you-that is, whether he or she is a relevant expert. This is where the informal channel is so powerful. To use Internet terms, the informal channel has a very high "bandwidth," the more so in face-to-face interaction (including "bedside manner"), and to a lesser, but still significant, extent in epistolary exchanges between already familiar persons. Lots of information can be conveyed through the informal channel-for example, via inflections of mood and tone, by communications geared specifically to you, and by finely tuned reactions to responses received. And by definition, the informal channel is relevant because you are one of the parties to exchanges in it. ${ }^{149}$

Cheyne was a virtuoso in using the informal channel. His letters did not have to be used as tokens of his relevant expertise, because in large

149. For the informational richness and moral consequence of the face-to-face domain, see the classic work of Erving Goffman, The Presentation of Self in the Everyday Life (London: Allen Lane, 1959). And see Steven Shapin, A Social History of Truth: Civility and Science in Seventeenth-Century England (Chicago: University of Chicago Press, 1994), esp. chaps. 3 and 6. 
part they were the thing itself. The letters not only said that he cared about his individual patients, they were a major way in which such caring was instantiated. As a way of establishing his authority, Cheyne's masterful use of the informal channel worked quite well. Far more than the public literary display of ontological expertise, this was what enabled him to persuade some of his patients, some of the time, to follow a dietetic regime of asses' milk and seeds, and so to fly in the face of tradition, appetite, and common sense. 